\title{
Pola Spasial dan Keputusan Keluarga Bermukim di Permukiman Kumuh Pusat Kota dan Wilayah Pinggiran Kota Malang, Jawa Timur
}

\author{
Irvan Ardiansyah dan Satti Wagistina
}

${ }^{I}$ Program Studi Geografi, Jurusan Geografi, Universitas Negeri Malang, Jawa Timur, Indonesia

Koresponden Email: satti.wagistina.fis@um.ac.id

Direvisi: 2020-12-23 . Diterima: 2021-03-17

(C)2021 Fakultas Geografi UGM dan Ikatan Geograf Indonesia (IGI)

\begin{abstract}
Abstrak. Perkembangan kawasan permukiman kumuh di Kota Malang disebabkan oleh faktor urbanisasi dan penduduk asli yang penghasilan rendah sehingga berakibat pada rendahnya daya beli terhadap rumah layak huni dan berlokasi di zona permukiman ideal. Kedua golongan masyarakat ini mendorong untuk memilih lokasi bermukim di wilayah yang tidak seharusnya dijadikan kawasan permukiman sehingga menyebakan kemunculan kawasan permukiman kumuh baru. Tujuan penelitian ini adalah; 1) mengetahui pola spasial permukiman kumuh pusat kota dan wilayah pinggiran; 2) mengetahui hubungan kondisi sosial ekonomi masyarakat terhadap permukiman kumuh pusat kota dan wilayah pinggiran. Wilayah kajian permukiman kumuh pusat Kota Malang berada di Kelurahan Kauman, sedangkan wilayah pinggiran berada di Kelurahan Tlogomas. Kedua wilayah tersebut berdasarkan SK Walikota Malang termasuk dalam kawasan permukiman kumuh yang terdapat di Kota Malang. Penelitian ini menggunakan pendekatan kuantitatif. Alat analisis yang digunakan yakni Sistem Informasi Geografis (SIG) dengan metode overlay untuk mengetahui pola spasial permukiman kumuh. Untuk mengetahui keputusan keluarga bermukim di permukiman kumuh digunakan uji regresi logistik ordinal. Hasil penelitian menunjukkan kawasan permukiman kumuh pusat kota memiliki pola linier sepanjang Sungai Kasin. Kawasan permukiman kumuh wilayah pinggiran memiliki pola linier dan memusat. Hasil analisis regresi logistik ordinal menunjukkan keputusan keluarga bermukim di permukiman kumuh secara signifikan dipengaruhi oleh kondisi sosial ekonomi yang meliputi tingkat pendidikan, jumlah anggota keluarga, dan kebutuhan ekonomi untuk permukiman kumah pusat Kota Malang. Keputusan keluarga untuk bermukim di permukiman kumuh wilayah pinggiran dipengaruhi oleh kebutuhan ekonomi, pendapatan, jumlah anggota keluarga, dan jenis pekerjaan.
\end{abstract}

Kata kunci: Permukiman kumuh, pola permukiman, pusat kota, wilayah pinggiran

\begin{abstract}
The emergent growing of slums in Malang City has been caused by urbanization and the locals with low income making it hard for them to afford proper housing located in ideal residential zones. These two groups of societies have triggered the choice to reside in the improper areas, and thus new slums emerge. This current study aimed at: 1) describing the spatial pattern of the slums in the down town and suburb area; and 2) investigating the correlation between socio-economic conditions of the societies and the slums in the down towan and suburb area. The slum in down town Malang City was Kauman Sub-district; while the slum in the suburb area was Tlogomas Sub-district. Both locations have been pronounced as the slums within the Decree Statement of the Mayor of Malang. This study was conducted by means of quantitative approach. Geographic Information System (GIS) was employed as the analysis. Overlay method was used to detect the spatial patterns of the slums and ordinal logistic regression was performed to investigate the correlation between socio-economic conditions of the societies and the slums. It has been revealed that the slum in the downtown portrayed a linear pattern along Kasin river bank. The slum in the suburb area showed linear and centered patterns. The ordinal logistic regression analysis resulted in the notion that the decision to reside in the slums has been significantly affected by the socio-economic conditions. The results of ordinal-logistic regression analysis showed that the family's decision to live in the slum was significantly influenced by socio-economic conditions including education level, number of family members, and economic needs for slum in the downtown. The family's decision to live in the slum areas in surburb area was influenced by economic needs, income, number of family members, and their professions.
\end{abstract}

Keywords: Slums, settlement patterns, downtown, suburb area

\section{PENDAHULUAN}

Perkembangan permukiman kumuh perkotaan disebabkan oleh dua faktor yaitu angka pertumbuhan penduduk yang tinggi dan urbanisasi (Yunus, 2007). Jumlah penduduk Kota Malang pada tahun 2015 sebesar 851,298 jiwa, mengalami pertambahan pada tahaun 2019 sebanyak 19,384 jiwa dengan total penduduk 870,682 jiwa. Pendatang di Kota Malang pada tahun 2015 sebanyak 241.672 jiwa, mengalami peningkatan pada tahun 2019 sebanyak 5,225 jiwa dengan total pendatang adalah 246,897 jiwa.

Pertambahan jumah penduduk kota menyebabkan kebutuhan ruang dan penyediaan sarana prasarana permukiman meningkat, sedangkan ketersediaan lahan strategis untuk permukiman tidak mengalami penambahan (Budiharjo, 2005). Kondisi tersebut menyebabkan penduduk 
kota memanfaatkan lahan terbatas untuk dijadikan tempat permukiman tanpa memperhatikan kualitas lingkungan di dalamnya. Pembangunan permukiman pada lahan terbatas menimbulkan masalah alih fungsi lahan yang tidak sesuai dengan ketentuan fungsi ruang, sehingga menyebabkan berkembangnya kawasan permukiman kumuh baru di kota.

Kawasan permukiman kumuh adalah lingkungan hunian yang kualitasnya tidak layak huni. Ciri dari permukiman kumuh antara lain berada pada lahan yang tidak sesuai dengan peruntukan/ tata ruang, kepadatan bangunan sangat tinggi dalam luasan yang sangat terbatas, kualitas bangunan yang sangat rendah, tidak terlayani prasaran lingkungan yang memadai dan membahayakan keberlangsungan kehidupan dan penghidupan penghuninya (Budiharjo, 2005).

Beberapa lokasi permukiman di Kota Malang tergolong sebagai permukiman kumuh. Luas permukiman kumuh di Kota Malang adalah 608,60 Ha yang meliputi 29 kelurahan di lima kecamatan. Permukiman kumuh di Kota Malang memiliki tingkat kepadatan yang lebih tinggi dari perkampungan, berlokasi di sepanjang aliran sungai, sekitar rel kereta api, dan berdekatan dengan beberapa perkampungan Pada umumnya kondisi bangunan pada permukiman kumuh di Kota Malang adalah permanen, hanya beberapa bagian saja yang terbuat dari bahan semi permanen (Dinas PU Kota Malang, 2014).

Lokasi penelitian di dua kelurahan yang berkategori kumuh sebagaimana yang tertuang Surat Keputusan Walikota Malang No. 188.45/86/35.73.112/2015 tentang penetapan lingkungan perumahan dan permukiman kumuh. Kelurahan yang berada di pusat kota sesuai dengan regulasi tersebut adalah Kelurahan Kauman, sedangkan wilayah pinggiran berada di Kelurahan Tlogomas. Luas permukiman kumuh yang sebesar 4,20\% dari luas wilayah Kota Malang merupakan suatu penyakit kota. Perwujudan lingkungan fisik perkotaan yang memiliki nilai arsitektural kota menjadi berkurang. Aspek kenyamanan, keamanan, dan keindahan kota menjadi berkurang sehingga berdampak pada potensi daya tarik dari keindahan visual lokasi tidak muncul.

Kecenderungan perkembangan permukiman kumuh yang makin meluas harus diantisipasi. Arah perkembangannya di Kota Malang harus diidentifikasi sedini mungkin agar cakupan permukiman kumuh tidak semakin meluas sehingga berdampak pada penurunan nilai estetika kota. Arah perkembangan tersebut dapat ditinjau dari pola spasial permukiman kumuh. Pola spasial tersebut secara langsung menggambarkan proses spasial permukiman kumuh. Proses spasial merupakan perpaduan antara faktor lingkungan, budaya, ekonomi, dan sosial. Oleh karena itu untuk penanganan permukiman kumuh, faktor non fisik juga sangat penting diprioritaskan.

Penelitian ini bertujuan untuk : 1) mengidentifikasi pola permukiman kumuh di pusat kota dan wilayah pinggiran
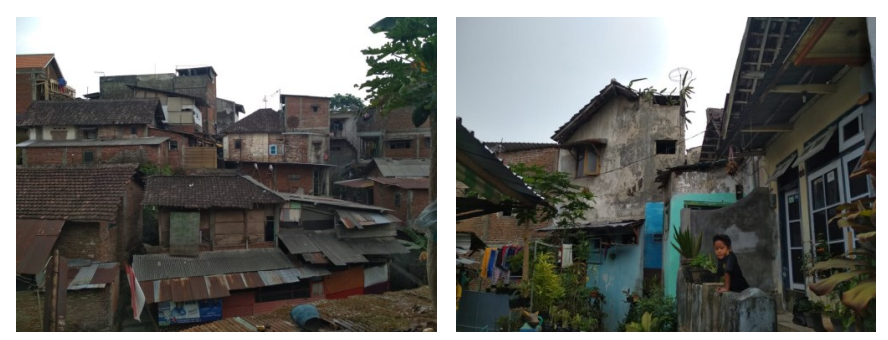

Gambar 1. Kawasan Permukiman Kumuh Kota Malang (Sumber: Dokumentasi Lapangan, 2020)
Kota Malang; 2) untuk mengetahui faktor pembentuk yang melatarbelakangi keluarga dalam memutuskan bermukim di permukiman kumuh pusat kota dan wilayah pinggiran Kota Malang. Metode yang digunakan untuk mengetahui pola spasial permukiman kumuh yaitu metode Sistem Informasi Geografis (SIG), analisis overlay dan deliniasi batas kawasan permukiman kumuh melalui hasil ground checking.SIG digunakan untuk memfasilitasi proses pemasukan, penyimpanan manipulasi, menampilkan dan keluaran data informasi geografi beserta atribut-atribut yang berkaitan dari suatu objek atau fenomena yang berkaitan dengan letak atau kondisi di permukaan bumi (Ekadinata, 2008). Metode overlay merupakan suatu sistem informasi dalam bentuk grafis yang dibentuk dari penggabungan beberapa peta individu. Overlay peta dilakukan dengan 2 (dua) jenis peta yang berbeda, secara teknis dikatakan harus ada polygon yang terbentuk dari 2 (dua) jenis peta yang dioverlaykan (Rachmah et al. 2018).

Penelitian ini bermanfaat dalam memberikan perspektif yang berbeda dalam penanganan permukiman kumuh. Berbeda halnya dengan penelitian oleh Wijaya (2016), Amri (2013), Maharani dan Umilia (2014), Barbara dan Umilia (2014). Keempat penelitian tersebut memfokuskan penelitian pada aspek fisik permukiman kumuh dan menggunakan metode a-spasial dalam analisisnya seperti metode SWOT dan metode statistik deskriptif. Penelitian ini menggabungkan aspek spasial dan sosial ekonomi untuk menggambarkan permukiman kumuh yang berada di pusat kota dan wilayah pinggiran Kota Malang. Oleh karena itu analisis data dalam penelitian ini menggabungkan metode spasial dan a-spasial (analisis regresi logistik ordinal). Lokasi penelitian yang berada di pusat kota dan wilayah pinggiran bermanfaat dalam menghasilkan informasi dan gambaran tentang perbedaan dan persamaan karakteristik permukiman kumuh. Penanganan permasalahan permukiman kumuh akan menjadi efektif apabila karakteristik fisik dan non fisik telah diketahui.

\section{METODE PENELITIAN}

Pendekatan penelitian ini adalah kuantitatif. Pendekatan kuantitatif ditunjukkan dari penggunaan metode SIG berupa analisis overlay untuk mengetahui pola spasial permukiman kumuh pusat Kota Malang dan wilayah pinggiran. Selain itu pendekatan kuantitatif juga digunakan untuk menganalisis hubungan kondisi sosial ekonomi masyarakat terhadap keputusan keluarga bermukim di permukiman kumuh pusat kota dan wilayah pinggiran melalui uji regresi logistik ordinal. Lokasi penelitian permukiman kumuh pusat kota berada di Kelurahan Kauman, Kecamatan Klojen, untuk permukiman kumuh wilayah pinggiran berada di Kelurahan Tlogomas, Kecamatan Lowokwaru. Lokasi penelitian ditentukan secara sengaja (purposive sampling) dengan mengacu pada Surat Keputusan Walikota Malang Nomor 188.45/86/35.73.112/2015 tentang penetapan lingkungan perumahan dan permukiman kumuh. Lebih lanjut wilayah penelitian dapat dilihat pada Gambar 2 dan 3.

Jenis data yang digunakan dalam penelitian meliputi data primer dan data sekunder. Data primer meliputi pendapatan ekonomi, kebutuhan ekonomi, tingkat pendidikan, jumlah anggota keluarga, dan jenis pekerjaan responden. Data primer dikumpulkan melalui wawancara, ground checking, dan studi dokumentasi untuk mengetahui kondisi permukiman kumuh. 


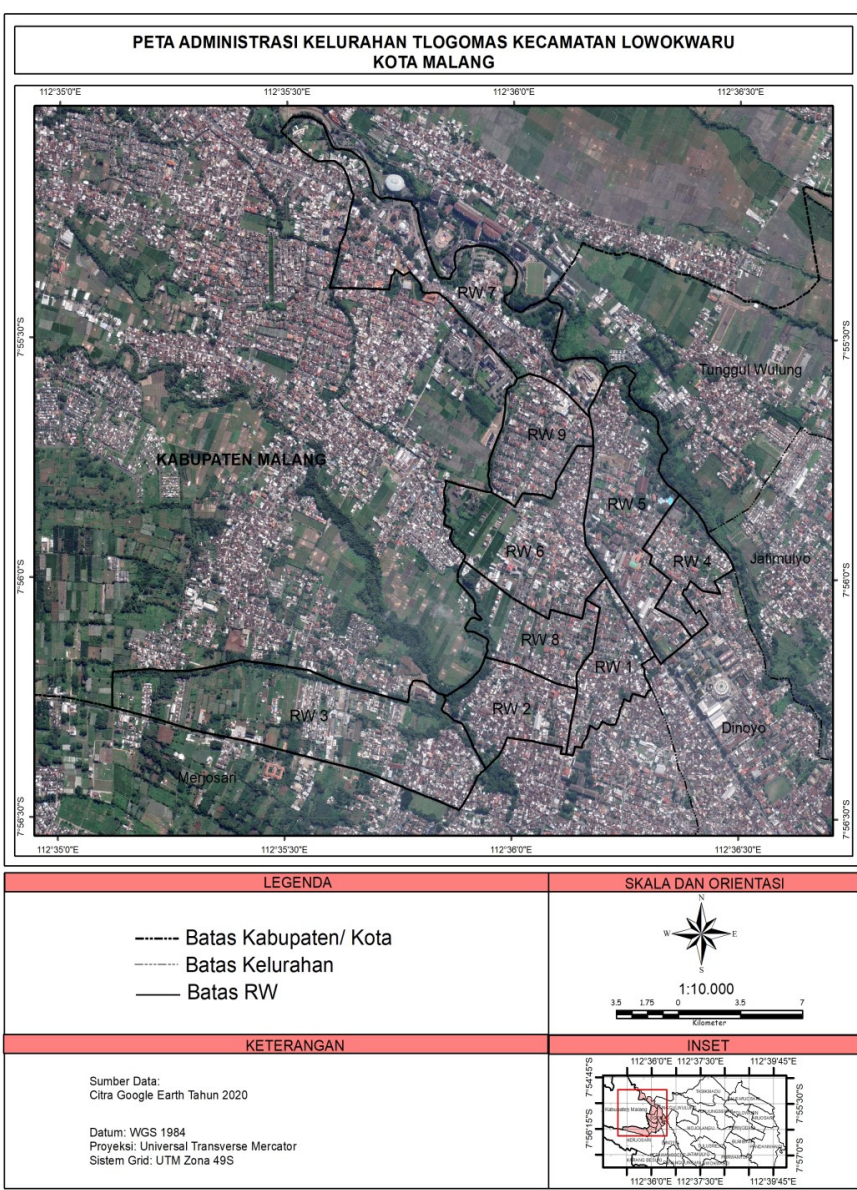

Data sekunder yang digunakan adalah penggunaan lahan

Gambar 2. Peta Administrasi Kelurahan Tlogomas

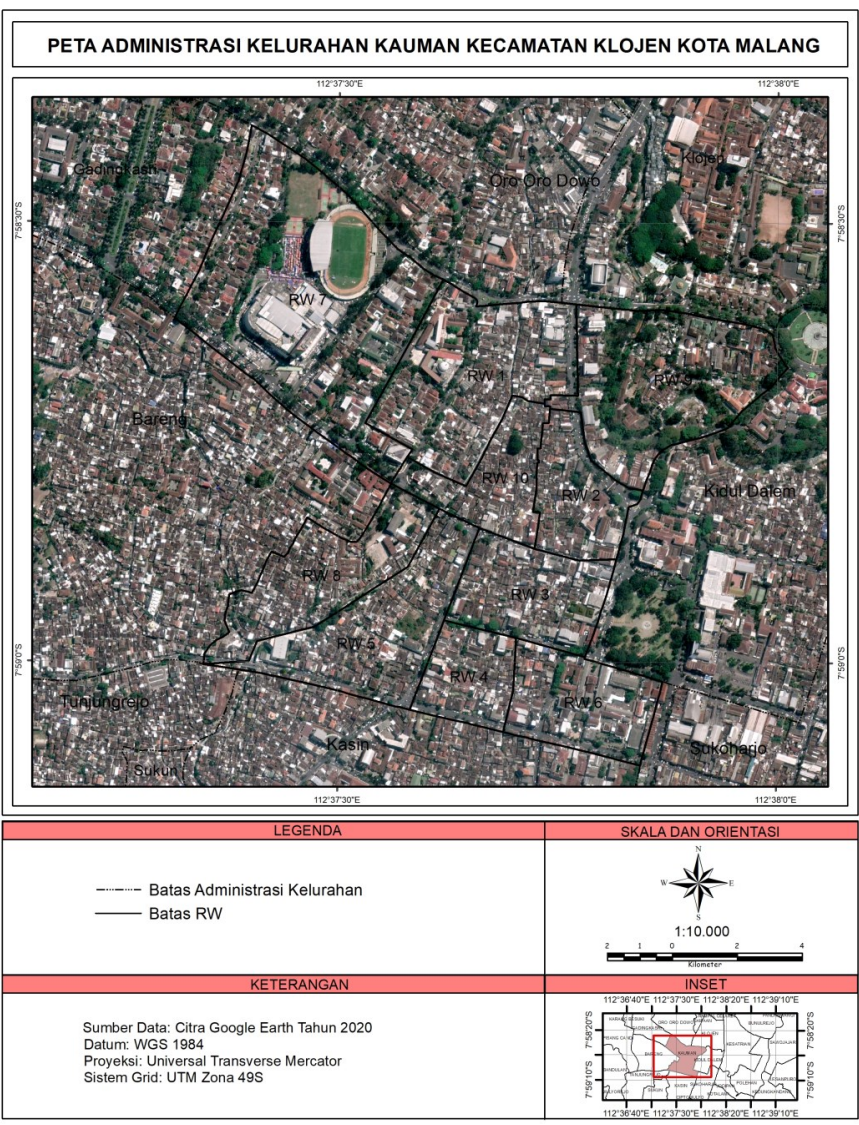

Gambar 3. Peta Administrasi Kelurahan Kauman di pusat kota dan wilayah pinggiran. Data penggunaan lahan bersumber dari data citra Google Earth. Data citra tersebut dipergunakan untuk membuat peta penggunaan lahan Kelurahan Kauman dan Tlogomas tahun 2020. Data sekunder lainnya adalah peta digital Rencana Detail Tata Ruang Kota (RDTRK) Malang Utara dan Malang Tengah tahun 2016-2036 skala 1:10000. Data tersebut digunakan untuk menganalisis pola spasial permukiman kumuh.

\section{Populasi dan Sampel Penelitian}

Populasi dalam penelitian adalah kepala keluarga (KK) yang bermukim di permukiman kumuh pusat kota dan wilayah pinggiran. Jumlah KK di permukiman kumuh pusat kota (Kelurahan Kauman) adalah sebanyak $3.212 \mathrm{KK}$, dan wilayah pinggiran (Kelurahan Tlogomas) sebanyak 4.718. Dari jumlah populasi yang ada selanjutnya ditentukan jumlah sampel dengan menggunakan metode Slovin (Siregar, 2013). Hasil perhitungan dengan metode Slovin diperoleh jumlah sampel sebanyak $96 \mathrm{KK}$ di pusat kota dan $99 \mathrm{KK}$ di wilayah pinggiran. Total jumlah sampel dalam penelitian ini adalah $195 \mathrm{KK}$.

Selanjutnya adalah membagi sampel kedalam kriteria tingkat kekumuhan permukiman. Metode yang digunakan adalah sampel bertingkat (stratified sampling) dengan kriteria kumuh ringan, sedang, dan berat. Penentuaan tingkat kekumuhan adalah dengan cara memberikan pembobotan pada enam indikator permukiman kumuh yang meliputi:kepadatan penduduk, kepadatan bangunan, pelayanan jaringan jalan lingkungan, ketidakteraturan bangunan, sistem pengelolaan air limbah, dan sistem pengelolaan persampahan. Berdasarkan metode sampel bertingkat maka permukiman kumuh di pusat kota terdapat 32 sampel untuk masing-masing tingkat kekumuhan sehingga total terdapat $96 \mathrm{KK}$. Permukiman kumuh di wilayah pinggiran terdapat 33 sampel untuk masing-masing tingkat kekumuhan sehingga terdapat $99 \mathrm{KK}$. Responden dipilih secara simple random sampling artinya tiap unit keluarga memiliki kesempatan yang sama untuk dipilih sebagai responden penelitian.

\section{Analisis Overlay}

Analisis overlay digunakan untuk mengetahui pola spasial permukiman kumuh pusat kota dan wilayah pinggiran Kota Malang. Data input yang digunakan dalam analisis overlay adalah; (1) peta digital Rencana Detail Tata Ruang dan Peraturan Zonasi Bagian Wilayah Perkotaan Malang Tengah dan Malang Utara pada skala 1:10000 yang diperoleh dari Badan Perencanaan Pembangunan Daerah Kota Malang; (2) peta penggunaan lahan Kelurahan Kauman dan Tlogomas tahun 2020 pada skala 1:10000 yang diperoleh dari citra Google Earth tahun 2020. Alat bantu yang digunakan dalam analisis overlay adalah program ArcGIS. Dalam analisis overlay langkah pertama yang dilakukan adalah:1) pilih menu overlay pada program ArcGIS; 2) pilih menu union; 3) input peta digital Rencana Detail Tata Ruang dan Peraturan Zonasi Bagian Wilayah Perkotaan Malang Tengah dan Malang Utara pada skala 1:10000 dan peta penggunaan lahan Keluarahan Kauman dan Tlogomas. Langkah ketiga ini dilakukan secara terpisah. Output yang dihasilkan dari analisis overlay adalah peta eksisting penggunaan lahan di Kelurahan Kauman dan Tlogomas pada skala 1:10000.Tahap berikutnya dilakukan ground checking (cek lapangan) untuk keperluan validasi dan identifikasi 
batas kawasan permukiman kumuh. Identifikasi batas kawasan permukiman kumuh berdasarkan peta eksisiting pada wilayah yang mengalami perubahan penggunaan lahan menjadi kawasan permukiman. Identifikasi tersebut memperhatikan 4 (empat) aspek berupa: kepadatan bangunan, ketidak teraturan bangunan, kondisi persampahan, dan pelayanan jaringan jalan lingkungan. Berdasarkan hasil cek lapangan selanjutnya ditetapkan batas kawasan permukiman kumuh pusat kota dan wilayah pinggiran Kota Malang.

\section{Analisis Regresi Logistik Ordinal}

Analisis ini bertujuan untuk mengetahui faktor-faktor yang berpengaruh terhadap keputusan keluarga untuk bermukim di permukiman kumuh. Faktor-faktor yang dimaksud adalah kondisi sosial ekonomi keluarga. Data kondisi sosial ekonomi diperoleh melalui wawancara terhadap 195 responden dan hasilnya diolah dengan menggunakan program olah data SPSS 20.

Untuk kepentingan pengujian maka ditentukan variable terikat dan bebas. Variabel terikat (dependent) dalam penelitian ini adalah tingkat kekumuhan permukiman dan variabel bebas (independent) adalah pendapatan, kebutuhan ekonomi, jumlah anggota keluarga, jenis pekerjaan, dan tingkat pendidikan. Pengujian regresi logistik ordinal dilakukan dengan beberapa tahap sebagai berikut:

1.Uji Validitas

Pada tahap pra penelitian, validitas instrumen diujikan pada 195 responden. Uji validasi menggunakan pendekatan confirmatory factor analysis (CFA), melalui uji Kaiser-Meyer Olkin (KMO) dan Balett's Test. Bila nilai KMO measure of sampling adequency (KMO MSA) > 0,50 maka proses analisis dapat dilanjutkan dan data dinyatakan valid.

2. Uji Reliabilitas

Uji reliabilitas merupakan alat untuk mengukur suatu kuisioner sebagai indikator dari variabel atau konstruk. Kuisioner dikatakan reliable atau handal apabila jawaban responden terhadap pernyataan adalah konsisten atau stabil. Kuisioner dikatakan reliable atau handal apabila jawaban responden terhadap pernyataan adalah konsisten atau stabil. Maka semakin tinggi tingkat reliabilitas suatu alat pengukur maka semakin stabil pula alat pengukuran tersebut. Dalam SPSS diberikan menu analisis untuk mengukur reliabilitas melalui uji statistik Cronbach's Alpha ( $\alpha$ ). Suatu konstruk atau variabel dikatakan reliable jika memberikan nilai Cronbach's Alpha > 0,6 (Ghozali, 2011).

\section{Uji Multikoliniearitas}

Uji multikolinearitas dilakukan untuk melihat kebebasan antar variabel independen. Variabel bebas $\left(\mathrm{X}_{1}, \mathrm{X}_{2}, \mathrm{X}_{3}, \mathrm{X}_{4}\right.$, dan $\mathrm{X}_{5}$ ) tidak bersifat multikolinearitas apabila nilai $\mathrm{VIF} \leq 10$.

4.Uji Paralle Lines

Dalam model proportional odds, terdapat sebuah asumsi penting yaitu asumsi paralle lines, yang berarti besar odds ratio tidak terpengaruh oleh variabel dependen dikotomisasikan. Maka jika terdapat sebuah variabel dependen dengan jumlah kategori sebanyak J, hanya ada satu estimasi parameter (B) untuk tiap variabel independen dan J-1 estimasi (a) yang berbeda. Asumsi ini dapat diuji menggunakan uji rasio log likelihood. Model regresi memiliki koefisien regresi (slope) yang sama untuk semua variabel dan asumsi parallel lines terpenuhi apabila nilai $p$-value $>0,05$.

5. Uji Kecocokan Model
Pengujian ini bertujuan untuk mengetahui apakah persamaan model yang telah dibentuk sesuai. Statistik uji yang digunakan adalah uji pearson. Model dinyatakan sesuai apabila nilai $p$-value $>0,05$.

2. Uji Simultan

Pengujian secara simultan bertujuan untuk memeriksa peran variabel independen yang diajukan terhadap varaiabel dependen secara bersama-sama. Statistik uji yang digunakan adalah uji rasio Likelihood (Likelihood Ratio Test). Variabel penelitian dinyatakan simultan apabila nilai $P$-Value $<0,05$, yang artinya ada variabel bebas yang berpengaruh secara signifikan terhadap variabel terikat.

7. Uji Pendugaan Parameter Secara Parsial

Pengujian secara parsial bertujuan untuk menguji signifikansi masing-masing parameter sehingga dapat diketahui variabel bebas yang memiliki pengaruh nyata terhadap variabel terikat. Uji statistik yang digunakan adalah uji Wald. Hasil uji menunjukkan terdapat variabel independen tertentu yang berpengaruh secara signifikan terhadap variabel dependen apabila nilai $P$-value $<0,05$.

8. Perhitungan nilai Odds Ratio

Odds ratio menggambarkan kecenderungan suatu bagian populasi pada kategori tertentu terhadap bagian populasi pada kategori lainnya, pada suatu variabel bebas yang memiliki pengaruh signifikan terhadap variabel terikat (Raharjanti \& Widiharih, 2005). Nilai odds ratio diperoleh dengan persamaan berikut:

$¥=\exp \left(\beta_{\mathrm{i}}\right)$, dimana, exp: $(2,71828)$ dan $\beta_{\mathrm{I}}$ : nilai estimasi hasil uji statistik variabel bebas yang berpengaruh terhadap variabel terikat.

\section{HASIL DAN PEMBAHASAN}

Pola Spasial Permukiman Kumuh Pusat Kota dan Wilayah Pinggiran

1. Pola Spasial Permukiman Kumuh Pusat Kota Malang

Permukiman kumuh pusat kota Malang memiliki luas sebesar 1,69 $\mathrm{Ha}$, berlokasi di koordinat $7^{\circ} 58^{\prime} 58.7^{\prime \prime} \mathrm{S}, 112^{\circ}$ $37^{\prime} 29,2^{\prime \prime}$ E dan $7^{\circ} 58^{\prime} 57,2^{\prime} \mathrm{S}, 112^{\circ} 37^{\prime} 26,8^{\prime \prime}$ E. Secara administratif lokasi dengan pada koordinat tersebut berada di wilayah RW 5 dan 8 Kelurahan Kauman. Berikut adalah hasil cek lapangan pada peta eksisting penggunaan lahan Keluarahan Kauman, Kecamatan Klojen, Kota Malang.

Berdasarkan hasil cek lapangan yang merupakan dasar untuk melakukan deliniasi, maka kawasan permukiman kumuh pusat kota ditunjukkan oleh gambar 4 .

Hasil perhitungan menunjukkan bahwa persentase bangunan tidak teratur melebihi 50\%. Artinya adalah permukiman kumuh didominasi oleh bangunan yang secara arsitektural tidak memiliki nilai estetika. Kondisi ini berdampak pada kenyamanan di lingkungan perkotaan. Tabel 2 juga menunjukkan jika kondisi permukiman kumuh di pusat Kota Malang memiliki karakteristik berupa kepadatan bangunan yang tinggi. Kawasan permukiman kumuh di RW 5 memiliki kepadatan lebih tinggi daripada di RW 8. Persentase bangunan tidak teratur lebih besar di RW 8 dibandingkan RW 5.

Hasil penelitian menunjukan permukiman kumuh pusat Kota Malang membentuk pola linier sepanjang Sungai Kasin. Pola tersebut merupakan pola umum permukiman kumuh di kota-kota besar Indonesia (Direktorat Jendral Perumahan dan Permukiman, 2002). Permukiman kumuh di pusat kota Malang yang berlokasi di zona bantaran sungai telah menyalahi regulasi. Berdasarkan peraturan Menteri 
Tabel 1. Hasil Cek Lapangan Batas Kawasan Permukiman Kumuh Pusat Kota di Kota Malang

\begin{tabular}{|c|c|c|}
\hline RW & koordinat & Keterangan \\
\hline \multirow{6}{*}{5} & $7^{\circ} 58^{\prime} 58.5^{\prime \prime} \mathrm{S}, 112^{\circ} 37^{\prime} 27.4^{\prime \prime} \mathrm{E}$ & $\begin{array}{l}\text { Batas antara kawasan permukiman padat penduduk bantaran sungai } \\
\text { dengan pabrik }\end{array}$ \\
\hline & $7^{\circ} 58^{\prime} 57.7^{\prime \prime} \mathrm{S}, 112^{\circ} 37^{\prime} 28.1^{\prime \prime} \mathrm{E}$ & Batas antara kawasan permukiman padat penduduk dengan sungai \\
\hline & $7^{\circ} 58^{\prime} 59.7^{\prime \prime} \mathrm{S}, 112^{\circ} 37^{\prime} 29.5^{\prime \prime} \mathrm{E}$ & $\begin{array}{l}\text { Batas antara kawasan permukiman padat penduduk bantaran sungai } \\
\text { dengan kawasan perumahan }\end{array}$ \\
\hline & $7^{\circ} 58^{\prime} 57.5^{\prime \prime} \mathrm{S}, 112^{\circ} 37^{\prime} 30.3^{\prime \prime} \mathrm{E}$ & $\begin{array}{l}\text { Batas antara kawasan permukiman padat penduduk bantaran sungai } \\
\text { dengan jalan lingkungan }\end{array}$ \\
\hline & $7^{\circ} 58^{\prime} 57.0^{\prime \prime} \mathrm{S}, 112^{\circ} 37^{\prime} 30.8^{\prime \prime} \mathrm{E}$ & $\begin{array}{l}\text { Batas antara kawasan permukiman padat penduduk bantaran sungai } \\
\text { dengan jalan lingkungan }\end{array}$ \\
\hline & $7^{\circ} 58^{\prime} 56.6^{\prime \prime} \mathrm{S}, 112^{\circ} 37^{\prime} 31.4^{\prime \prime} \mathrm{E}$ & $\begin{array}{l}\text { Batas antara kawasan permukiman padat penduduk bantaran sungai } \\
\text { dengan kawasan perumahan }\end{array}$ \\
\hline \multirow{8}{*}{8} & $7^{\circ} 58^{\prime} 56.0^{\prime \prime} \mathrm{S}, 112^{\circ} 37^{\prime} 30.7^{\prime \prime} \mathrm{E}$ & Batas antara kawasan permukiman padat penduduk dengan sungai \\
\hline & $7^{\circ} 58^{\prime} 58.0^{\prime \prime} \mathrm{S}, 112^{\circ} 37^{\prime} 24.1^{\prime \prime} \mathrm{E}$ & $\begin{array}{l}\text { Batas antara kawasan permukiman padat penduduk di bantaran sungai } \\
\text { dengan jalan lingkungan }\end{array}$ \\
\hline & $7^{\circ} 58^{\prime} 56.8^{\prime \prime} \mathrm{S}, 112^{\circ} 37^{\prime} 24.6^{\prime \prime} \mathrm{E}$ & $\begin{array}{l}\text { Batas antara kawasan permukiman padat di bantaran sungai dengan } \\
\text { kawasan perumahan }\end{array}$ \\
\hline & $7^{\circ} 58^{\prime} 55.6^{\prime \prime} \mathrm{S}, 112^{\circ} 37^{\prime} 24.7^{\prime \prime} \mathrm{E}$ & Batas jalan lingkungan dengan jalan arteri/ jalan umum \\
\hline & $7^{\circ} 58^{\prime} 55.9^{\prime \prime} \mathrm{S}, 112^{\circ} 37^{\prime} 25.5^{\prime \prime} \mathrm{E}$ & $\begin{array}{l}\text { Batas antara kawasan permukiman bantaran sungai dengan jalan ar- } \\
\text { teri/ jalan umum }\end{array}$ \\
\hline & $7^{\circ} 58^{\prime} 55.2^{\prime \prime} \mathrm{S}, 112^{\circ} 37^{\prime} 26.4^{\prime \prime} \mathrm{E}$ & $\begin{array}{l}\text { Batas antara kawasan permukiman padat di bantaran sungai dengan } \\
\text { kawasan perumahan }\end{array}$ \\
\hline & $7^{\circ} 58^{\prime} 55.7^{\prime \prime} \mathrm{S}, 112^{\circ} 37^{\prime} 28.7^{\prime \prime} \mathrm{E}$ & $\begin{array}{l}\text { Batas antara kawasan permukiman padat di bantaran sungai dengan } \\
\text { kawasan perumahan }\end{array}$ \\
\hline & $7^{\circ} 58^{\prime} 56.5^{\prime \prime} \mathrm{S}, 112^{\circ} 37^{\prime} 29.1^{\prime \prime} \mathrm{E}$ & Batas antara kawasan permukiman padat penduduk dengan sungai \\
\hline
\end{tabular}

(Sumber: Hasil Ploting Lapangan Peta Eksisting Penggunaan Lahan Kelurahan Kauman)

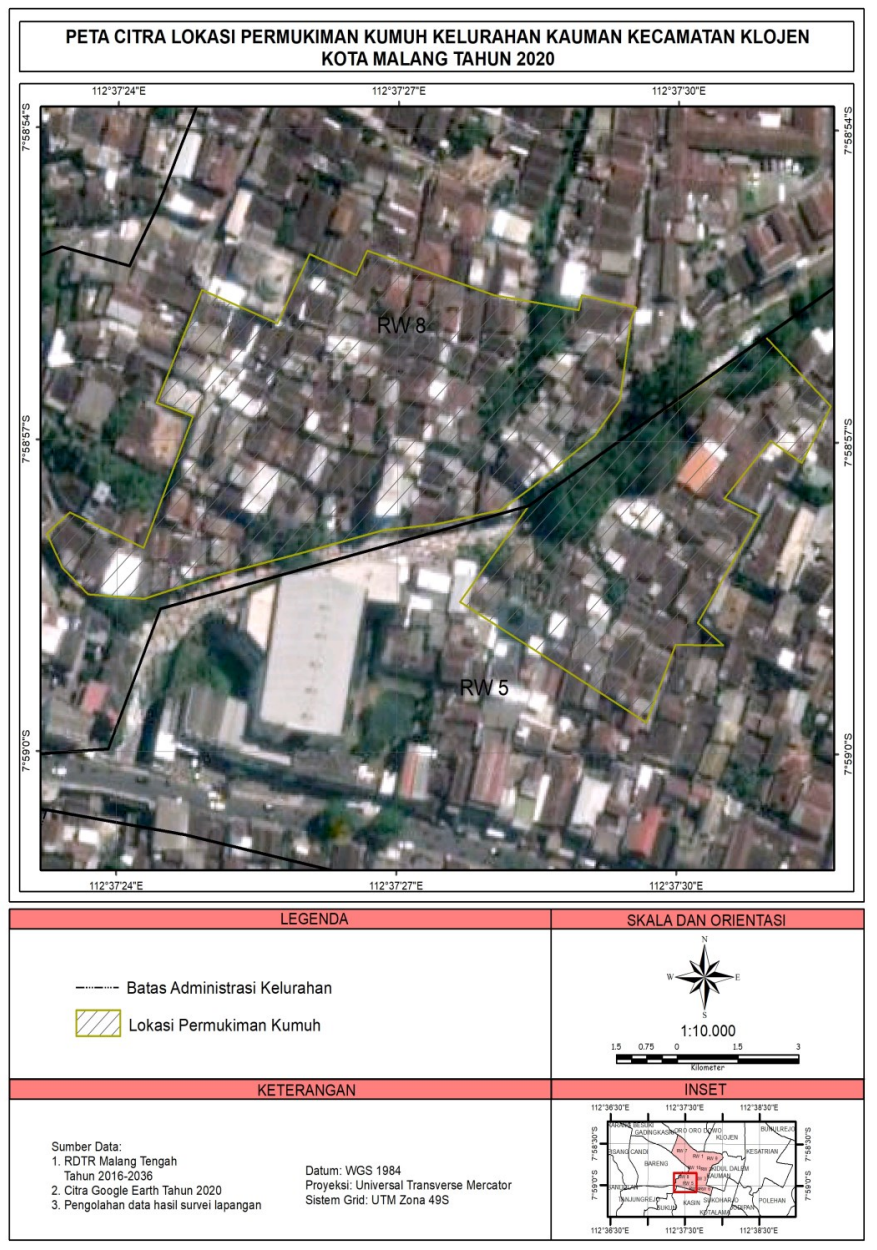

Gambar 4. Lokasi Permukiman Kumuh Pusat Kota Malang

(Sumber: Hasil Digitasi Citra Google Earth, 2020)
Pekerjaan Umum dan Perumahan Rakyat No 28 Tahun 2015 pasal 7 telah diatur bahwa sungai bertanggul pada wilayah perkotaan diukur dari kaki tanggul sebelah luar sepanjang 3 meter ditetapkan fungsinya sebagai wilayah sempadan sungai dan tidak diijinkan untuk didirikan bangunan. Artinya adalah apabila terdapat kawasan permukiman didalamnya maka lahan tersebut tidak bisa didaftarkan sebagai hak milik perseorangan atau pribadi. Implikasinya adalah permukiman kumuh pusat kota tidak memiliki hak kepemilikan.

Dampak negatif permukiman kumuh di bantaran sungai yaitu terganggunya ekosistem sungai Kasin. Hal ini diakibatkan oleh pembuangan limbah domestik ke sungai dan kawasan permukiman sangat padat, sehingga tidak terdapat ruang untuk difungsikan sebagai septic tank atau fasilitas pengelolaan limbah rumah tangga lainnya. Pembuahan limbah domestik secara langsung mengakibatkan terjadinya pencemaran sungai. Sahabuddin et al. ( 2014) menjelaskan bahwa pencemaran air sungai karena limbah domestik dapat berasal dari kawasan permukiman penduduk yang berada di sekitar sungai yang langsung membuang limbah rumah tangga ke sungai tanpa proses pengolahan. Nursyamsiah (2015) menjelaskan jika permukiman
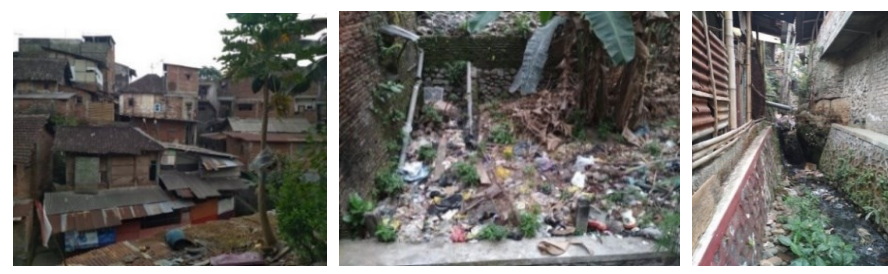

Gambar 5. (a) Kondisi Kepadatan Bangunan

Kawasan Permukiman Kumuh Pusat Kota, (b)

Kondisi Persampahan, (c) Kondisi Drainase Lingkungan

(Sumber: Hasil Survei Lapangan, 2020) 
kumuh pada umumnya mengalami kondisi seperti di pusat Kota Malang yakni terganggunya fungsi sungai, tidak adanya jarak antar bangunan, sampah dan limbah tidak dikelola dengan baik, serta tidak terpeliharanya sarana dan prasarana dalam kawasan permukiman.

Kawasan permukiman kumuh pusat kota terbentuk karena berkembangnya kawasan permukiman yang tidak direncanakan dan tidak terkontrol sehingga terjadi penurunan kualitas lingkungan permukiman. Hal ini sesuai dengan hasil penelitian oleh Ndolu, et al (2017). Jika sesuai dengan dokumen perencanaan ruang, yakni Rencana Detail Tata Ruang dan Peraturan Zonasi Bagian Wilayah Perkotaan Malang Tengah tahun 2016-2036, maka lokasi permukiman kumuh yang ada saat ini memiliki fungsi kawasan perlindungan setempat. Artinya telah terjadi penyimpangan penggunaan lahan.

Kawasan permukiman kumuh kota disebabkan oleh keterlambatan pemerintah kota dalam merencanakan dan membangun prasarana pada wilayah permukiman. Di sisi yang lain masyarakat secara swadaya memecah bidang tanah dan membangun permukiman. Aktivitas masyarakat Kota Malang yang seperti ini tanpa didasari perencanaan tapak, akibatnya bentuk dan letak kavling tanah menjadi tidak teratur dan tidak dilengkapi dengan prasarana dasar permukiman. Faktor yang demikian juga juga menyebabkan berkembangnya permukiman kumuh baru pada wilayah kota sebagaimana yang dinyatakan juga oleh Mut'ali (2016).

Permukiman kumuh bantaran sungai terbentuk karena pertambahan jumlah penduduk baik secara alami ataupun karena faktor urbanisasi. Pertambahan jumlah penduduk yang terus terjadi menyebabkan permintaan hunian di kota mengalami peningkatan, sedangkan lahan perkotaan tetap. Masyarakat berpenghasilan rendah (MBR) memilih lokasi rumah yang dekat dengan lokasi pekerjaannya, karena semakin jauh tempat bekerja maka semakin besar biaya perjalanannya (komuting). Oleh karena itu disekitar pusat kota

Tabel 2. Kepadatan Bangunan Dan Persentase Bangunan Tidak Teratur Permukiman Kumuh di Pusat Kota Malang

\begin{tabular}{ccccccc}
\hline & \multicolumn{3}{c}{ Kepadatan bangunan } & \multicolumn{3}{c}{ Persentase bangunan tidak teratur } \\
\cline { 2 - 7 } RW & $\begin{array}{c}\text { Jumlah } \\
\text { Bangunan } \\
(\text { Unit })\end{array}$ & $\begin{array}{c}\text { Luas Wilayah } \\
(\text { Ha) }\end{array}$ & $\begin{array}{c}\text { Kepadatan Bangunan } \\
(\text { Unit/Ha) }\end{array}$ & $\begin{array}{c}\text { Jumlah } \\
\text { Bangunan } \\
\text { (Unit) }\end{array}$ & $\begin{array}{c}\text { Jumlah } \\
\text { Bangunan Tidak } \\
\text { Teratur }\end{array}$ & $\begin{array}{c}\text { Persentase } \\
\text { Bangunan Tidak } \\
\text { Teratur }\end{array}$ \\
\hline 5 & 40 & 0,60 & 66 & 40 & 27 & 67,50 \\
8 & 105 & 1,09 & 96 & 105 & 92 & 87,61 \\
\hline
\end{tabular}

(Sumber: Hasil Digitasi Citra Google Earth, 2020)

Tabel 3. Hasil Cek Lapangan Batas Kawasan Permukiman Kumuh Wilayah Pinggiran Kota Malang (Sumber: Hasil Ploting Lapangan Peta Eksisting Penggunaan Lahan Kelurahan Tlogomas)

\begin{tabular}{|c|c|c|}
\hline RW & koordinat & Keterangan \\
\hline \multirow{6}{*}{1} & $7^{\circ} 56^{\prime} 14.7^{\prime \prime} \mathrm{S}, 112^{\circ} 36^{\prime} 17.4^{\prime \prime} \mathrm{E}$ & $\begin{array}{l}\text { Batas antara kawasan permukiman padat penduduk bantaran sungai dengan } \\
\text { perumahan }\end{array}$ \\
\hline & $7^{\circ} 56^{\prime} 13.8^{\prime \prime} \mathrm{S}, 112^{\circ} 36^{\prime} 18.2^{\prime \prime} \mathrm{E}$ & Batas antara kawasan permukiman padat penduduk dengan jalan raya \\
\hline & $7^{\circ} 56^{\prime} 12.7^{\prime \prime} \mathrm{S}, 112^{\circ} 36^{\prime} 17.6^{\prime \prime} \mathrm{E}$ & $\begin{array}{l}\text { Batas antara kawasan permukiman padat penduduk bantaran sungai dengan } \\
\text { kawasan perumahan }\end{array}$ \\
\hline & $7^{\circ} 56^{\prime} 12.5^{\prime \prime} \mathrm{S}, 112^{\circ} 36^{\prime} 16.7^{\prime \prime} \mathrm{E}$ & $\begin{array}{l}\text { Batas antara kawasan permukiman padat penduduk bantaran sungai dengan } \\
\text { perumahan }\end{array}$ \\
\hline & $7^{\circ} 56^{\prime} 13.5^{\prime \prime} \mathrm{S}, 112^{\circ} 36^{\prime} 16.5^{\prime \prime} \mathrm{E}$ & $\begin{array}{l}\text { Batas antara kawasan permukiman padat penduduk bantaran sungai dengan } \\
\text { perumahan }\end{array}$ \\
\hline & $7^{\circ} 56^{\prime} 13.4^{\prime \prime} \mathrm{S}, 112^{\circ} 36^{\prime} 15.3^{\prime \prime} \mathrm{E}$ & $\begin{array}{l}\text { Batas antara kawasan permukiman padat penduduk bantaran sungai dengan jalan } \\
\text { lingkungan }\end{array}$ \\
\hline \multirow{13}{*}{2} & $7^{\circ} 56^{\prime} 14.1^{\prime \prime} \mathrm{S}, 112^{\circ} 36^{\prime} 14.6^{\prime \prime} \mathrm{E}$ & Batas antara kawasan permukiman padat penduduk dengan ruang terbuka hijau \\
\hline & $7^{\circ} 56^{\prime} 15.4^{\prime \prime} \mathrm{S}, 112^{\circ} 35^{\prime} 53.0^{\prime \prime} \mathrm{E}$ & Batas antara kawasan permukiman padat penduduk dengan sungai \\
\hline & $7^{\circ} 56^{\prime} 14.6^{\prime \prime} \mathrm{S}, 112^{\circ} 35^{\prime} 54.2^{\prime \prime} \mathrm{E}$ & Batas antara kawasan permukiman padat penduduk dengan sungai \\
\hline & $7^{\circ} 56^{\prime} 12.6^{\prime \prime} \mathrm{S}, 112^{\circ} 35^{\prime} 53.0^{\prime \prime} \mathrm{E}$ & Batas antara kawasan permukiman padat penduduk dengan sungai \\
\hline & $7^{\circ} 56^{\prime} 15.4^{\prime \prime} \mathrm{S}, 112^{\circ} 35^{\prime} 55.7^{\prime \prime} \mathrm{E}$ & Batas antara kawasan permukiman padat penduduk dengan sungai \\
\hline & $7^{\circ} 56^{\prime} 12.1^{\prime \prime} \mathrm{S}, 112^{\circ} 35^{\prime} 56.5^{\prime \prime} \mathrm{E}$ & $\begin{array}{l}\text { Batas antara kawasan permukiman padat di bantaran sungai dengan kawasan } \\
\text { perumahan }\end{array}$ \\
\hline & $7^{\circ} 56^{\prime} 12.2^{\prime \prime} \mathrm{S}, 112^{\circ} 35^{\prime} 57.4^{\prime \prime} \mathrm{E}$ & $\begin{array}{l}\text { Batas antara kawasan permukiman padat di bantaran sungai dengan kawasan } \\
\text { perumahan }\end{array}$ \\
\hline & $7^{\circ} 56^{\prime} 12.6^{\prime \prime} \mathrm{S}, 112^{\circ} 35^{\prime} 58.3^{\prime \prime} \mathrm{E}$ & Batas antara kawasan permukiman padat penduduk dengan perumahan \\
\hline & $7^{\circ} 56^{\prime} 12.6^{\prime \prime} \mathrm{S}, 112^{\circ} 35^{\prime} 58.3^{\prime \prime} \mathrm{E}$ & Batas antara kawasan permukiman padat penduduk dengan perumahan \\
\hline & $7^{\circ} 56^{\prime} 13.2^{\prime \prime} \mathrm{S}, 112^{\circ} 35^{\prime} 58.5^{\prime \prime} \mathrm{E}$ & Batas antara kawasan permukiman padat penduduk dengan perumahan \\
\hline & $7^{\circ} 56^{\prime} 15.6^{\prime \prime} \mathrm{S}, 112^{\circ} 35^{\prime} 57.5^{\prime \prime} \mathrm{E}$ & Batas antara kawasan permukiman padat penduduk dengan perumahan \\
\hline & $7^{\circ} 56^{\prime} 14.6^{\prime \prime} \mathrm{S}, 112^{\circ} 35^{\prime} 55.9^{\prime \prime} \mathrm{E}$ & Batas antara kawasan permukiman padat penduduk dengan jalan raya \\
\hline & $7^{\circ} 56^{\prime} 16.7^{\prime \prime} \mathrm{S}, 112^{\circ} 35^{\prime} 55.0^{\prime \prime} \mathrm{E}$ & Batas antara kawasan permukiman padat penduduk dengan jalan raya \\
\hline
\end{tabular}


banyak didapati rumah yang tumbuh secara bertahap, baik legal maupun illegal, kumuh maupun liar (Tharziansyah, 2016).

Permukiman kumuh pusat Kota Malang berada pada lahan yang tidak seharusnya menjadi kawasan permukiman, berdasarkan peraturan yang ada pada jarak 3 meter diukur dari kaki tanggung sebelah luar Sungai Kasin ditetapkan sebagai lahan terbuka hijau yang memilki fungsi alami sebagai wilayah serapan limpasan permukaan. Apabila dijadikan sebagai kawasan permukiman maka fungsi alami sempadan sungai tersebut hilang, sehingga menyebabkan keseimbangan ekosistem sungai dalam penyerapan air hasil limpasan terganggu, akibatnya limpasan sungai meluas ke kawasan permukiman dan mengakibatkan bencana banjir. Kejadian banjir yang pernah dialami permukiman kumuh pusat kota adalah tahun 2017.

2. Pola Spasial Permukiman Kumuh Wilayah Pinggiran Kota Malang

Lokasi permukiman kumuh berada di koordinat $7^{\circ} 56$ $12,0^{\prime \prime} \mathrm{S}, 112^{\circ} 36^{\prime} 17.1^{\prime \prime} \mathrm{E}, \mathrm{RW} 2$ di koordinat $7^{\circ} 56^{\prime} 14.0^{\prime \prime} \mathrm{S}$, dan $112^{\circ} 35^{\prime} 56.6^{\prime \prime} \mathrm{E}$ dan secara admiistratif termasuk RW 1 dan 2 Kelurahan Tlogomas. Berikut adalah cek lapangan peta eksisting penggunaan lahan Keluarahan Tlogomas, Kecamatan Lowokwaru, Kota Malang.
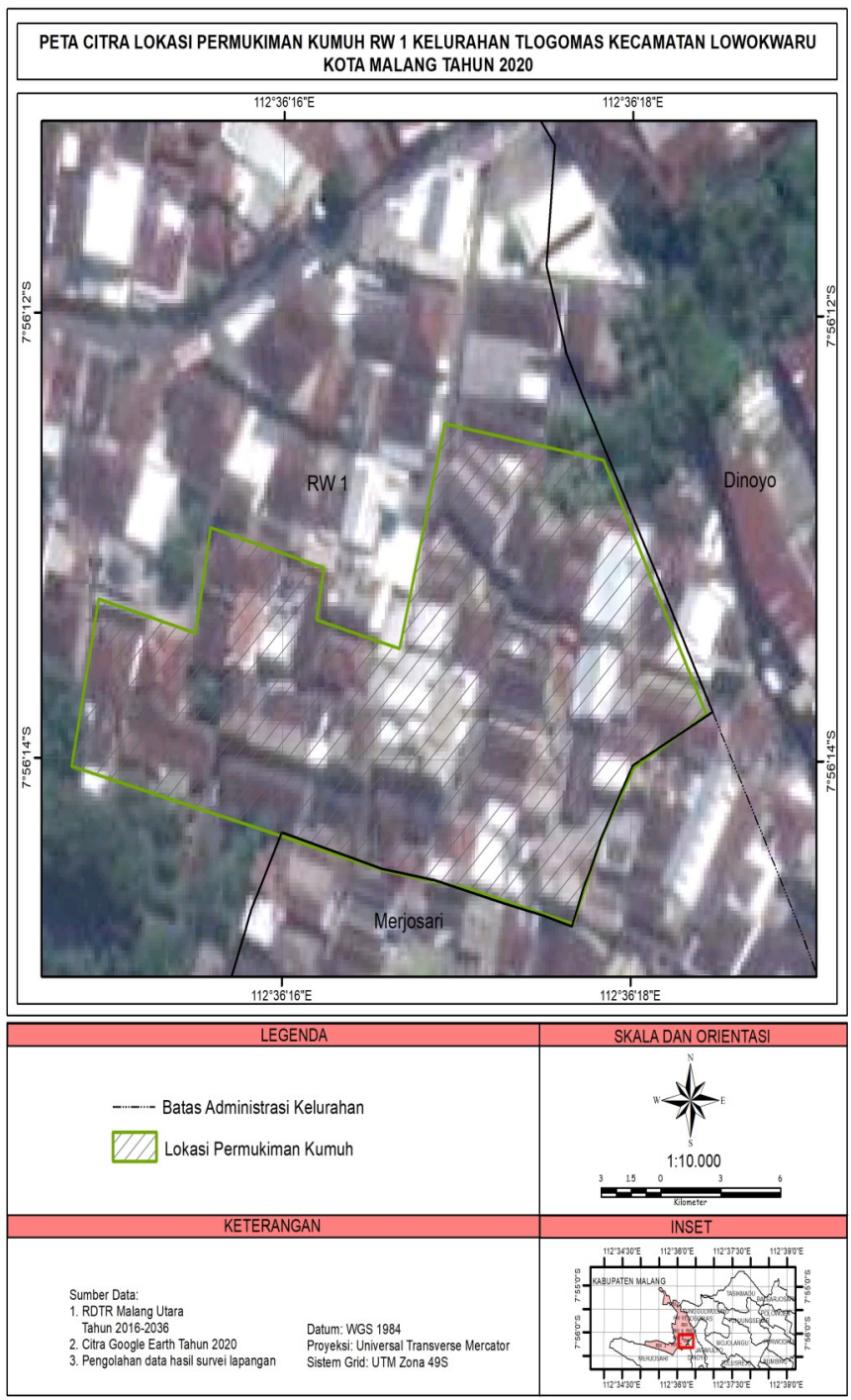

Berdasarkan hasil survei dan validasi lapangan selanjutnya dilakukan deliniasi kawasan permukiman kumuh. Hasil deliniasi kawasan permukiman kumuh wilayah pinggiran Kota Malang dapat dilihat pada gambar 6 .

Hasil perhitungan menunjukkan persentase bangunan tidak teratur melebihi 50\%. Artinya adalah kondisi permukiman kumuh wilayah pinggiran sama dengan di pusat kota. Bangunan tidak teratur di RW 1 mendominasi dibandingkan di RW 2. Tabel 6 juga menunjukkan jika kondisi permukiman kumuh di wilayah pinggiran memiliki karakteristik berupa kepadatan bangunan yang tinggi hingga mencapai 90 unit/Ha. Hampir tidak ada jarak antar rumah sehingga menimbulkan derajat kualitas lingkungan permukiman yang rendah.

Hasil deliniasi lokasi permukiman kumuh wilayah pinggiran Kota Malang menunjukkan terdapat dua pola yakni; 1) linier sepanjang Sungai Sub DAS Metro; 2) mengelompok di zona permukiman yang berdekatan dengan batas Kelurahan Tlogomas dan Kelurahan Dinoyo. Permukiman kumuh yang membentuk pola linier mempunyai luas $0,98 \mathrm{Ha}$, sedangkan yang membentuk pola mengelompok memiliki luas $0.43 \mathrm{Ha}$. Dari hasil cek lapangan diperoleh temuan bahwa kawasan permukiman kumuh memiliki permasalahan lingkungan berupa

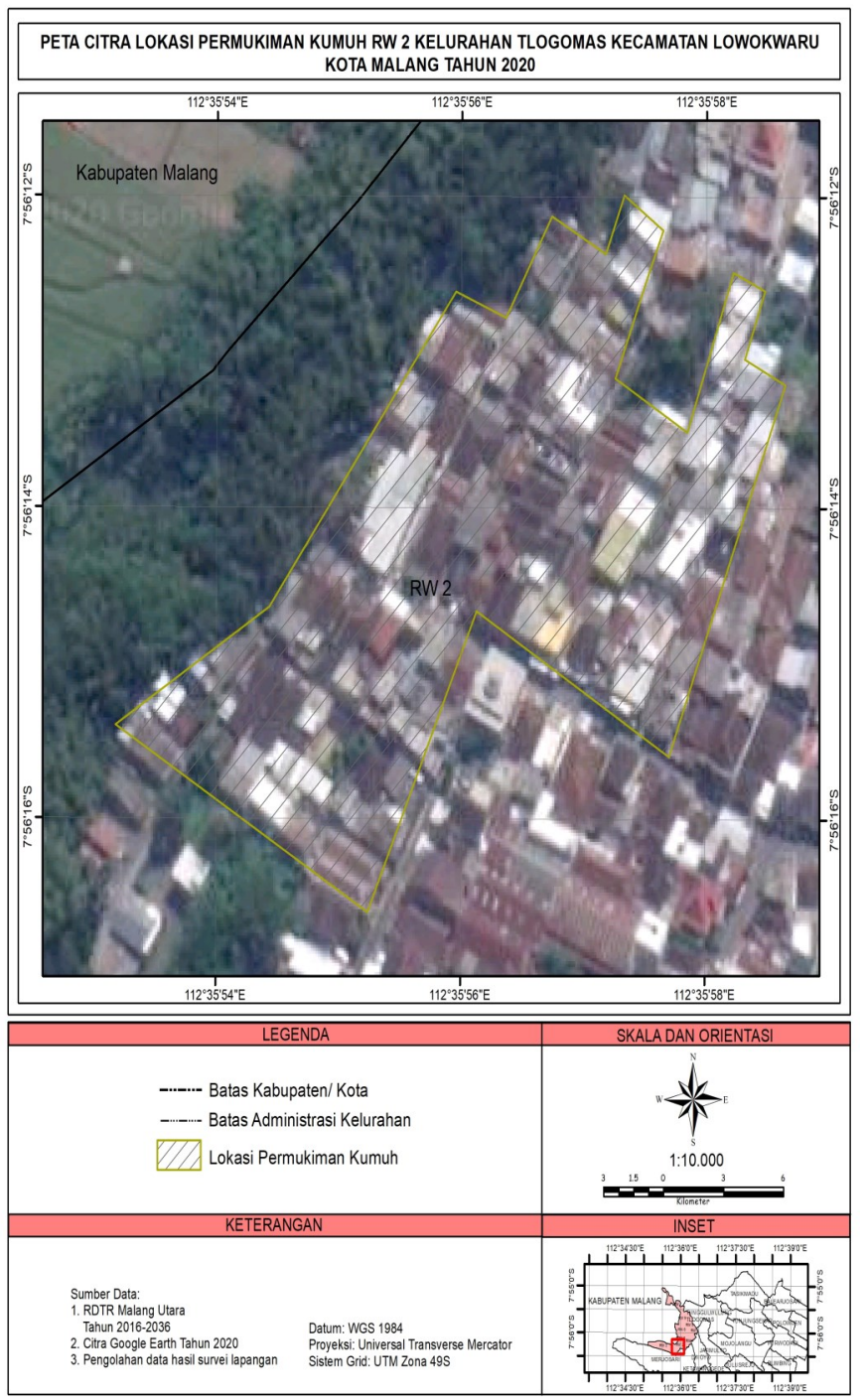

Gambar 6. Lokasi Permukiman Kumuh Wilayah Pinggiran Kota Malang (Sumber: Hasil Digitasi Citra Google Earth, 2020) 
Tabel 4. Kepadatan Bangunan Dan Persentase Bangunan Tidak Teratur Permukiman Kumuh di Wilayah Pinggiran Kota Malang

(Sumber: Hasil Digitasi Citra Google Earth, 2020)

\begin{tabular}{ccccccc}
\hline & \multicolumn{3}{c}{ Kepadatan bangunan } & \multicolumn{2}{c}{ Persentase bangunan tidak teratur } \\
\cline { 2 - 7 } RW & $\begin{array}{c}\text { Jumlah } \\
\text { Bangunan } \\
\text { (Unit) }\end{array}$ & $\begin{array}{c}\text { Luas } \\
\text { Wilayah (Ha) }\end{array}$ & $\begin{array}{c}\text { Kepadatan Bangunan } \\
\text { (Unit/Ha) }\end{array}$ & $\begin{array}{c}\text { Jumlah } \\
\text { Bangunan } \\
\text { (Unit) }\end{array}$ & $\begin{array}{c}\text { Jumlah } \\
\text { Bangunan Tidak } \\
\text { Teratur }\end{array}$ & $\begin{array}{c}\text { Persentase } \\
\text { Bangunan Tidak } \\
\text { Teratur }\end{array}$ \\
\cline { 2 - 7 } 1 & 79 & 0,98 & 80 & 79 & 63 & 79,74 \\
2 & 39 & 0,43 & 90 & 39 & 22 & 56,41 \\
\hline
\end{tabular}

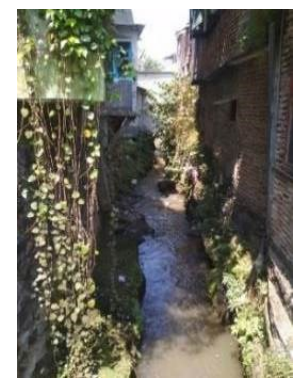

(a)

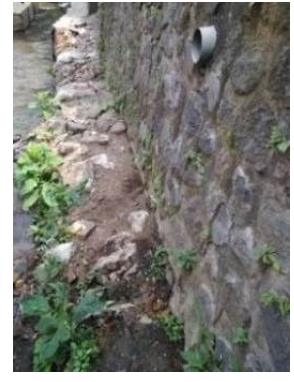

(b)
Gambar 7. (a) Kondisi Bangunan Kawasan

Permukiman Kumuh Pada Wilayah Pinggiran, (b) Kondisi Sistem Pengelolaan Limbah Rumah Tangga

(Sumber: Hasil Survei Lapangan, 2020)

pengelolaan air limbah tidak terencana serta pelayanan prasarana dasar permukiman yang buruh.

Pada Rencana Detail Tata Ruang dan Peraturan Zonasi Bagian Wilayah Perkotaan Malang Utara tahun 2016-2036, lokasi permukiman kumuh yang ada saat ini direncanakan sebagai fungsi kawasan perlindungan setempat, tetapi terjadi penyimpangan penggunaan lahan menjadi kawasan permukiman. Nursyahbani \& Bitta (2015) menjelaskan kawasan permukiman kumuh dapat diketahui berdasarkan kesesuaian antara pola penggunaan lahan dengan rencana pembangunan wilayah berdasarkan dokumen perencanaan ruang yang telah ditetapkan dan digunakan sebagai daar regulasi peruntukan ruang. Permukiman kumuh wilayah pinggiran terbentuk karena perkembangan wilayah yang tidak terencana dan ditandai dengan munculnya pusat pertumbuhan baru. Permukiman kumuh wilayah pinggiran selain karena pertambahan jumlah penduduk yang relatif tinggi juga karena perkembangan wilayah yang dipengaruhi oleh keberadaan beberapa kampus. Hasil survei lapangan menunjukkan bahwa beberapa keluarga responden menyediakan rumah sewa tinggal bagi mahasiswa yang berasal dari luar wilayah.

Keputusan keluarga bermukim di permukiman kumuh

Kepala Keluarga (KK) yang merupakan sampel dalam penelitian ini dibagi kedalam tiga kriteria tingkat kekumuhan. Kriteria tingkat kekumuhan dalam penelitian tampil di Tabel 5. Hasil penelitian menunjukkan bahwa kondisi sosial ekonomi keluarga di permukiman kumuh pusat kota dan wilayah pinggiran relatif homogen. Tingkat pendidikan,jenis pekerjaan dan jumlah anggota keluarga menunjukkan tidak terdapat perbedaan yang berarti antara keluarga permukiman kumuh pusat kota dan wilayah pinggiran. Pada variabel pendapatan dan kebutuhan ekonomi keluarga yang bertempat tinggal di permukiman kumuh ringan, sedang, dan berat relatif memiliki nominal kurang dari Rp.2.500.000,-/bulan.Kondisi sosial ekonomi keluarga yang bermukim di permukiman kumuh dengan tingkat kekumuhan ringan, sedang, dan berat berkontribusi

Tabel 5. Kriteria Tingkat Kekumuhan Permukiman (Sumber: Hasil Pengolahan Data)

\begin{tabular}{|c|c|c|c|}
\hline \multirow{2}{*}{ Kriteria } & \multicolumn{3}{|c|}{ Tingkat Kekumuhan } \\
\hline & Ringan & Sedang & Berat \\
\hline Kepadatan penduduk & $<150$ jiwa/ha & 151 jiwa/ha -200 jiwa/ha & $>200 \mathrm{jiwa} / \mathrm{ha}$ \\
\hline & Pusat kota: 5-28 unit/ha & Pusat kota: $29-57$ unit/ha & Pusat kota: $>57$ ujit/ha \\
\hline Kepadatan bangunan & $\begin{array}{l}\text { Wilayah pinggiran: } 20-31 \text { unit/ } \\
\text { ha }\end{array}$ & $\begin{array}{c}\text { Wilayah pinggiran: } 32-43 \text { unit/ } \\
\text { ha }\end{array}$ & $\begin{array}{c}\text { Wilayah pinggiran: }>43 \text { unit/ } \\
\text { ha }\end{array}$ \\
\hline $\begin{array}{l}\text { Pelayanan jaringan } \\
\text { jalan lingkungan }\end{array}$ & $\begin{array}{l}\text { 25\%-50\% area tidak terlayani } \\
\text { oleh jaringan jalan lingkungan }\end{array}$ & $\begin{array}{l}51 \%-75 \% \text { area tidak terlayani } \\
\text { oleh jaringan jalan lingkungan }\end{array}$ & $\begin{array}{c}\text { 76\%-100\% area tidak terlayani } \\
\text { oleh jaringan jalan ling- } \\
\text { kungan }\end{array}$ \\
\hline $\begin{array}{l}\text { Ketidakeraturan } \\
\text { bangunan }\end{array}$ & $\begin{array}{l}25 \%-50 \% \text { bangunan pada lokasi } \\
\text { tidak memiliki keteraturan }\end{array}$ & $\begin{array}{l}51 \%-75 \% \text { bangunan pada lokasi } \\
\text { tidak memiliki keteraturan }\end{array}$ & $\begin{array}{l}\text { 76\%-100\% bangunan pada } \\
\text { lokasi tidak memiliki ketera- } \\
\text { turan }\end{array}$ \\
\hline $\begin{array}{l}\text { Sistem pengelolaan air } \\
\text { limbah }\end{array}$ & $\begin{array}{c}25 \%-50 \% \text { area memiliki prasara- } \\
\text { na air limbah tidak sesuai per- } \\
\text { syaratan teknis }\end{array}$ & $\begin{array}{c}51 \%-75 \% \text { area memiliki prasa- } \\
\text { rana air limbah tidak sesuai } \\
\text { persyaratan teknis }\end{array}$ & $\begin{array}{l}76 \%-100 \% \text { area memiliki } \\
\text { prasarana air limbah tidak } \\
\text { sesuai persyaratan teknis }\end{array}$ \\
\hline $\begin{array}{l}\text { Sistem pengelolaan per- } \\
\text { sampahan }\end{array}$ & $\begin{array}{l}25 \%-50 \% \text { area tidak terlayani } \\
\text { fasilitas pengangkutan per- } \\
\text { sampahan }\end{array}$ & $\begin{array}{l}51 \%-75 \% \text { area tidak terlayani } \\
\text { fasilitas pengangkutan per- } \\
\text { sampahan }\end{array}$ & $\begin{array}{l}76 \%-100 \% \text { area tidak terlaya- } \\
\text { ni fasilitas pengangkutan per- } \\
\text { sampahan }\end{array}$ \\
\hline
\end{tabular}


Tabel 6. Data Kondisi Sosial Ekonomi Masyarakat Permukiman Kumuh Pusat Kota dan Wilayah Pinggiran Kota Malang (Sumber: Hasil Pengolahan Data)

\begin{tabular}{|c|c|c|c|}
\hline \multirow{2}{*}{ Kriteria } & \multicolumn{3}{|c|}{ Tingkat Kekumuhan } \\
\hline & Ringan & Sedang & Berat \\
\hline Kepadatan penduduk & $<150$ jiwa/ha & 151 jiwa/ha - 200 jiwa/ha & $>200 \mathrm{jiwa} / \mathrm{ha}$ \\
\hline & Pusat kota: 5-28 unit/ha & Pusat kota: $29-57$ unit/ha & Pusat kota: $>57$ ujit/ha \\
\hline Kepadatan bangunan & $\begin{array}{l}\text { Wilayah pinggiran: } 20-31 \text { unit/ } \\
\text { ha }\end{array}$ & $\begin{array}{l}\text { Wilayah pinggiran: } 32-43 \text { unit/ } \\
\text { ha }\end{array}$ & $\begin{array}{l}\text { Wilayah pinggiran: > } 43 \text { unit/ } \\
\text { ha }\end{array}$ \\
\hline $\begin{array}{l}\text { Pelayanan jaringan } \\
\text { jalan lingkungan }\end{array}$ & $\begin{array}{l}\text { 25\%-50\% area tidak terlayani } \\
\text { oleh jaringan jalan lingkungan }\end{array}$ & $\begin{array}{l}51 \%-75 \% \text { area tidak terlayani } \\
\text { oleh jaringan jalan lingkungan }\end{array}$ & $\begin{array}{l}76 \%-100 \% \text { area tidak terlaya- } \\
\text { ni oleh jaringan jalan ling- } \\
\text { kungan }\end{array}$ \\
\hline $\begin{array}{l}\text { Ketidakeraturan } \\
\text { bangunan }\end{array}$ & $\begin{array}{l}25 \%-50 \% \text { bangunan pada lokasi } \\
\text { tidak memiliki keteraturan }\end{array}$ & $\begin{array}{l}51 \%-75 \% \text { bangunan pada lokasi } \\
\text { tidak memiliki keteraturan }\end{array}$ & $\begin{array}{l}76 \%-100 \% \text { bangunan pada } \\
\text { lokasi tidak memiliki ketera- } \\
\text { turan }\end{array}$ \\
\hline $\begin{array}{l}\text { Sistem pengelolaan air } \\
\text { limbah }\end{array}$ & $\begin{array}{l}25 \%-50 \% \text { area memiliki prasara- } \\
\text { na air limbah tidak sesuai per- } \\
\text { syaratan teknis }\end{array}$ & $\begin{array}{l}51 \%-75 \% \text { area memiliki prasa- } \\
\text { rana air limbah tidak sesuai } \\
\text { persyaratan teknis }\end{array}$ & $\begin{array}{l}76 \%-100 \% \text { area memiliki } \\
\text { prasarana air limbah tidak } \\
\text { sesuai persyaratan teknis }\end{array}$ \\
\hline $\begin{array}{l}\text { Sistem pengelolaan per- } \\
\text { sampahan }\end{array}$ & $\begin{array}{l}25 \%-50 \% \text { area tidak terlayani } \\
\text { fasilitas pengangkutan per- } \\
\text { sampahan }\end{array}$ & $\begin{array}{l}51 \%-75 \% \text { area tidak terlayani } \\
\text { fasilitas pengangkutan per- } \\
\text { sampahan }\end{array}$ & $\begin{array}{l}76 \%-100 \% \text { area tidak terlaya- } \\
\text { ni fasilitas pengangkutan } \\
\text { persampahan }\end{array}$ \\
\hline
\end{tabular}

Tabel 7. Hasil Analisis Regresi Logistik Ordinal (Sumber: Hasil Wawancara Diolah)

\begin{tabular}{lcccc}
\hline \multicolumn{1}{c}{ Model } & -2 Log Likelihood & Chi-Square & df & Sig. \\
\hline Intercept Only & 100,193 & & & \\
Final & 52,054 & 48,139 & 5 &, 000 \\
\hline
\end{tabular}

besar pada pengambilan keputusan untuk bermukim. Hal ini dibuktikan dari hasil uji regresi logistik ordinal yang disajikan di Tabel 7 dan 8.

\section{Keputusan keluarga bermukim di permukiman kumuh} pusat Kota Malang

Berdasarkan hasil analisis regresi logistik ordinal,_keputusan keluarga yang tinggal di permukiman kumuh pusat kota sangat ditentukan oleh kondisi sosial ekonomi. Hal ini ditunjukkan dari nilai Chi-Square sebesar 48,139 dengan signifikansi 0,000. Hasil uji Wald menunjukkan terdapat 3 (tiga) variabel yang berpengaruh secara signifikan terhadap keputusan keluarga yakni tingkat pendidikan, jumlah anggota keluarga, dan kebutuhan ekonomi. Uji koefisien determinasi Nagelkerke sebesar 0,544 artinya tingkat pendidikan, jumlah anggota keluarga, dan kebutuhan ekonomi berkontribusi terhadap keputusan keluarga sebesar $54,40 \%$ dan sisanya sebesar $36,60 \%$ dipengaruhi oleh kondisi sosial ekonomi lainnya yang tidak termasuk dalam variabel penelitian ini. Hasil interpretasi persamaan regresi logistik ordinal dengan menggunakan uji rasio odd dihasilkan peluang dari satu responden pada variabel kebutuhan ekonomi sebesar 0,20 kali berpengaruh terhadap keputusan keluarga, diikuti dengan variabel jumlah anggota keluarga sebesar 0,18 kali, serta variabel tingkat pendidikan sebesar 0,10 kali.

Tingkat pendidikan berpengaruh secara signifikan terhadap keputusan keluarga untuk bermukim di permukiman kumuh pusat Kota Malang. Hasil penelitian menunjukkan rata-rata masyarakat di Kelurahan Kauman memiliki tingkat pendidikan menengah ke bawah. Kondisi tersebut berdampak pada jenis pekerjaan dan pendapatan yang diterima. Pada masyarakat dengan tingkat pendidikan tinggi akan menguasai keahlian di bidang tertentu, sedangkan masyarakat dengan tingkat pendidikan menengah ke bawah memiliki keterbatasan pada keahlian yang dimiliki, sehingga hanya mampu bekerja sebagai pekerja kasar dan pedagang keliling. Masyarakat dengan tingkat pendidikan menengah kebawah rata-rata bekerja di sektor informal seperti pedagang keliling, pekerja kasar dan buruh, jasa ojek, dan pedagang kecil. Masyarakat yang bekerja disektor tersebut memiliki permasalahan berupa pendapatan yang tidak bisa mencukupi kebutuhan ekonomi keluarga. Todaro (2000), menjelaskan bahwa pendidikan menjadi salah satu faktor penting dalam peningkatan produktivitas dan kemampuan untuk meningkatkan pendapatan baik jangka pendek maupun jangka panjang.

Faktor jumlah anggota keluarga berpengaruh terhadap keputusan keluarga di permukiman kumuh pusat kota. Jumlah anggota keluurga mempengaruhi biaya atau pengeluaran untuk kebutuhan hidup (Adiana \& Karmini, 2012). Rata-rata jumlah anggota keluarga adalah 4 orang. Semakin banyak jumlah anggota keluarga maka semakin besar pula pengeluaran yang harus disiapkan.

Kebutuhan ekonomi menjadi faktor paling besar yang berpengaruh terhadap penyebab keluarga memutusakan 
bermukim di permukiman kumuh. Kontribusi tersebut sebesar 0,20 kali. Kebutuhan ekonomi merupakan salah satu indikator kesejahteraan rumah tangga yang dipengaruhi oleh jumlah anggota keluarga dan pendapatan. Masyarakat yang bermukim pada wilayah dengan kategori kumuh berat memiliki kebutuhan ekonomi relatif rendah dibandingkan dengan masyarakat yang bermukim pada wilayah dengan kategori kumuh sedang dan kumuh ringan. Pendapatan yang dialokasikan untuk pemenuhan pangan memiliki porsi yang sangat besat dibandingkan untuk memenuhi kebutuhan non pangan. Hanum (2018), menjelaskan jumlah tanggungan keluarga dalam suatu rumah tangga akan mempengaruhi jumlah konsumsi yang harus dikeluarkan, semakin banyak tanggungan keluarga maka konsumsi yang harus dikeluarkan juga besar, begitu pula sebaliknya. Pola konsumsi masyarakat menyesuaikan antara kebutuhan ekonomi dan pendapatan yang diterima, agar mereka dapat terus memenuhi kebutuhan dasar atau pokok. Menurut Rachman (2001), pengeluaran konsumsi merupakan salah satu indikator kesejahteraan rumah tangga. Dalam hal ini rumah tangga dengan pengeluaran pangan rendah tergolong rumah tangga dengan tingkat kesejahteraan rendah dibandingkan rumah tangga yang proporsi pengeluaran pangannya tinggi. Selain itu jumlah tanggungan keluarga juga berpengaruh terhadap kebutuhan ekonomi masyarakat, dimana rumah tangga dengan jumlah tanggungan lebih banyak memiliki kebutuhan ekonmi yang lebih besar pula.

Keputusan keluarga bermukim di permukiman kumuh wilayah pinggiran Kota Malang

Keputusan keluarga bermukim di permukiman kumuh wilayah pinggiran ditentukan oleh kondisi sosial ekonomi. Hal ini ditunjukkan dari nilai Chi-Square sebesar 35,467 dengan signifikansi 0,000. Hasil uji Wald diketahui bahwa terdapat 4 (empat) variabel yang berpengaruh secara signifikan terhadap keputusan keluarga yakni kebutuhan ekonomi, pendapatan, anggota keluarga, dan mata pencaharian. Uji koefisien determinasi Nagelkerke sebesar 0,539 artinya kebutuhan ekonomi, pendapatan, anggota keluarga, dan mata pencaharian berpengaruh terhadap keputusan keluarga bermukim di permukiman kumuh wilayah pinggiran sebesar 53,90\% dan $46,10 \%$ dipengaruhi oleh kondisi sosial ekonomi lainnya yang tidak termasuk dalam variabel penelitian ini. Hasil interpretasi persamaan regresi logistik ordinal dengan menggunakan uji rasio odd dihasilkan peluang dari satu responden pada variabel kebutuhan ekonomi sebesar 3,57 kali berpengaruh terhadap keputusan keluarga untuk bermukim di permukiman kumuh, diikuti dengan variabel pendapatan sebesar 0,17 kali, jumlah anggota keluarga sebesar 0,14 kali, serta variabel mata pencaharian sebesar 0,19 kali.

Kondisi sosial ekonomi masyarakat yang mempengaruhi keputusan keluarga untuk bermukim di permukiman kumuh wilayah pinggiran meliputi:

Kebutuhan ekonomi, faktor ini memiliki kontribusi terhadap keputusan keluarga karena masyarakat dengan kebutuhan ekonomi rendah lebih memprioritaskan pemenuhan kebutuhan pokok pangan keluarga daripada kebutuhan non pangan seperti perbaikan kondisi fisik lingkungan permukiman yang berkaitan dengan kenyamanan tinggal. Kondisi tersebut menyebabkan masyarakat kurang memperhatikan aspek fisik hunian dan mengakibatkan penurunan kualitas lingkungan permukiman. Kebutuhan ekonomi masyarakat dipengaruhi oleh faktor jumlah tanggungan keluarga dan besarnya pendapatan ekonomi yang diterima (Rachman, 2001).

Pendapatan berkaitan dengan kesejahteraan keluarga, dimana kemampuan keluarga untuk memenuhi seluruh kebutuhan pokok tercukupi._. Apabila kebutuhan pokok keluarga tidak terpenuhi maka termasuk dalam kategori keluarga prasejahtera. Faktor yang berpengaruh terhadap pendapatan ekonomi yaitu jenis pekerjaan, dan waktu kerja. Mayoritas responden di Kelurahan Tlogomas bekerja di sektor informal. Sektor informal memilki permasalahan berupa upah dan waktu kerja yang tidak menentu. Pendapatan keluarga berpengaruh signifikan terhadap kontribusi tingkat kekumuhan permukiman, yakni responden dengan pendapatan ekonomi rendah, akan memberi kontribusi nyata terhadap perkembangan permukiman kumuh wilayah pinggiran. Hal tersebut tejadi karena pada masyarakat dengan penghasilan rendah lebih yang memprioritaskan pendapatan ekonominya untuk kebutuhan pokok keluarga, dan mengesampingkan perbaikan kondisi fisik rumah, sehingga menyebabkan penurunan kualitas lingkungan permukiman. Apabila tidak dilakukan upaya perbaikan rumah, maka akan menyebabkan berkembangnya kawasan permukiman kumuh baru wilayah pinggiran. Mut'ali (2016) menjelaskan pertumbuhan kota yang tinggi tetapi tidak diimbangi dengan tingkat pendapatan masyarakat yang cukup menjadi salah satu faktor terciptanya permukiman kumuh.

Jenis pekerjaan. Variabel jenis pekerjaan menentukan besaran upah yang diterima oleh responden. Jenis pekerjaan yang bergerak di sektor informal seperti buruh dan pekerja kasar, pedagang keliling, penyedia jasa informal memiliki ciri berupa upah yang diterima tergolong kecil dan tidak terdapat jam kerja yang teratur. Faktor yang berpengaruh terhadap jenis pekerjaan yaitu tingkat pendidikan dan ketrampilan yang dimiliki. Semakin tinggi tingkat pendidikan maka peluang untuk mendapatkan pekerjaan yang layak semakin besar. Di sisi yang lain, jenis pekerjaan berpengaruh pula terhadap keputusan bermukim di permukiman kumuh wilayah pinggiran. Karena secara langsung jenis pekerjaan berkaitan erat dengan pendapatan dan kesejahteraan keluarga. Apabila upah yang diterima tidak mencukupi kebutuhan keluarga, maka akan terjadi penurunan tingkat kesejahteraan keluarga sehingga akan mempengaruhi penuruan kualitas permukiman tempat tinggalnya. Menurut Ramadhan (2014) salah satu penyebab tingginya resistensi dari penghuni permukiman kumuh untuk tetap berada di lokasi semula adalah jarak yang dekat antara permukiman dengan pusat pusat pertumbuhan baru kota. Wilayah pinggiran Kota Malang berdekatan dengan Kota Batu yang mengalami perkembangan sebagai pusat pertumbuhan yakni

Tabel 8. Hasil Analisis Regresi Logistik Ordinal (Sumber: Hasil Wawancara Diolah)

\begin{tabular}{lcccc}
\hline \multicolumn{1}{c}{ Model } & -2 Log Likelihood & Chi-Square & df & Sig. \\
\hline Intercept Only & 101,020 & & & \\
Final & 65,553 & 35,467 & 6 &, 000 \\
\hline
\end{tabular}


pusat pariwisata dan industri kreatif.

Jumlah anggota keluarga berkaitan dengan tanggungan keluarga dan kebutuhan ekonomi. Apabila tanggungan keluarga banyak maka jumlah pengeluaran ekonomi besar, sehingga pendapatan ekonomi harus bisa memenuhi kebutuhan pokok tersebut. Rata-rata jumlah anggota keluarga di permukiman kumuh wilayah pinggiran adalah 4-5 orang. Jumlah ini sangat besar bila dibandingkan dengan rata-rata pendapatan yang diperoleh keluarga yang bermukim di permukiman kumuh wilayah pinggiran (Rp. 2.316.700,- per bulan). Pendapatan tersebut apabila dirata-rata berdasarkan jumlah anggota keluarga, maka per anggota keluarga hanya mendapatkan Rp. 579.175,- per bulan. Proporsi ini sangat kecil untuk pemenuhan kebutuhan ekonomi sehingga rentan memunculkan kelompok keluarga sejahtera dan pra sejahtera di wilayah perkotaan.

\section{KESIMPULAN}

Berdasarkan hasil penelitian dan pembahasan, dapat disimpulkan bahwa permukiman kumuh pusat kota memiliki pola linear sepanjang Sungai Kasin dengan luas 1,69 Ha. Permukiman kumuh wilayah pinggiran memiliki pola linear dan mengelopok. Luas permukiman kumuh yang membentuk pola linear adalah 0,98 $\mathrm{Ha}$, dan luas permukiman kumuh yang membentuk pola mengelompok adalah $0,43 \mathrm{Ha}$.

Keputusan keluarga bermukim di permukiman kumuh ditentukan oleh kondisi sosial ekonomi. Faktor kondisi sosial ekonomi keluarga yang bermukim di permukiman kumuh pusat kota meliputi tingkat pendidikan, jumlah anggota keluarga, dan kebutuhan ekonomi. Kontribusi dari ketiga kondisi sosial ekonomi tersebut sebesar 54,40\%. Berbeda halnya dengan keluarga yang bermukim di permukiman kumuh wilayah pinggiran yang ditentukan oleh kebutuhan ekonomi, pendapatan, jumlah anggota keluarga, dan jenis pekerjaan dengan kontribusi sebesar 53,90\%.

\section{UCAPAN TERIMA KASIH}

Penulis mengucapkan terimakasih kepada Yulius, Zulfikar, Satrio, Piska, Sarah, Lailatul, Ragil, Kresno yang membantu dalam pengambilan data lapangan. Ucapan terimakasih kepada Bapak Rudi Hartono dan Bapak Didik Taryana yang telah memberikan masukan pada proses penelitian ini. Ucapan terimakasih juga penulis sampaikan kepada Lurah Tlogomas dan Lurah Kauman yang telah memberikan ijin pelaksanaan penelitian.

\section{KONTRIBUSI PENULIS}

Penulis Pertama mendesain metode penelitian, pengumpulan data lapangan, dan menulis naskah publikasi. Penulis Kedua melakukan interpretasi data, analisis data, dan menulis naskah publikasi.

\section{DAFTAR PUSTAKA}

Adiana, P. P. E., \& Karmini, N. L. (2012). Pengaruh Pendapatan, Jumlah Anggota Keluarga dan Pendidikan Terhadap Pola Konsumsi Rumah Tangga Miskin di Kecamatan Gianyar. Jurnal Ekonomi Pembangunan Fakultas Ekonomi Universitas Udayana. Hal, 39-48.

Amri, N. (2013). Karakteristik Lingkungan Permukiman Kumuh Tepian Sungai Kecamatan Kolaka, Sulawesi Tenggara. Jurnal Jupiter, 12(1).

Barbara, P. B., \& Umilia, E. (2014). Clustering permukiman kumuh di kawasan pusat Kota Surabaya. Jurnal Teknik ITS, 3(2), C172-
C177.

Budiharjo, E. (2005). Tata Ruang Perkotaan. PT Alumni, Bandung.

Dinas Pekerjaan Umum Kota Malang. (2014). Profil Kawasan Kumuh di Kota Malang. Laporan tidak diterbitkan.

Direktorat Pengembangan Kawasan Permukiman. (2016). Panduan Penyusunan Rencana Pencegahan dan Peningkatan Kualitas Permukiman Kumuh Perkotaan (RP2KPKP). Jakarta: Direktorat Jenderal Cipta Karya Kementrian Pekerjaan Umum dan Perumahan Rakyat.

Ghozali, Imam. (2011). Aplikasi Analisis Multivariate Dengan Program IBM SPSS19, Semarang: Badan Penerbit Universitas Diponegoro.

Hanum, N. (2018). Pengaruh Pendapatan, Jumlah Tanggungan Keluarga Dan Pendidikan Terhadap Pola Konsumsi Rumah Tangga Nelayan Di Desa Seuneubok Rambong Aceh Timur. Jurnal Samudra Ekonomika, 2(1), 75-84.

Maharani, L. A., \& Umilia, E. (2014). Tipologi Permukiman Kumuh di Pinggiran Selatan Kota Surabaya. Jurnal Teknik ITS, 3(2), C102-C106.

Malau, W. (2013). Dampak Urbanisasi Terhadap Pemukiman Kumuh (Slum Area) di Daerah Perkotaan. JUPIIS: Jurnal Pendidikan Ilmu-Ilmu Sosial, 5(02), 39-47.

Muta'ali, L., \& Nugroho, A. R. (2016). Perkembangan program penanganan permukiman kumuh di Indonesia dari masa ke masa. Gadjah Mada University Press.

Ndolu, C., Effendi, J., \& Ramang, R. (2017). Kondisi Fisik Lingkungan Permukiman Yang Tumbuh Tidak Sesuai Peruntukan Lahan Dan Konsep Yang Terbentuk Dari Abstraksi Kondisi Permukiman Di Punggung Bukit Kelurahan Kelapa Lima Kota Kupang. Volume 17 No. 1, Pebruari 2017, hlm. 82-89.

Nursyahbani, R., \& Pigawati, B. (2015). Kajian Karakteristik Kawasan Pemukiman Kumuh di Kampung Kota (Studi Kasus: Kampung Gandekan Semarang). Teknik PWK (Perencanaan Wilayah Kota), 4(2), 267-281.

Nursyamsiyah, Siti., M. Thoha, B., Bakri, Samsul. (2015). FaktorFaktor Yang Menyebabkan Permukimankumuh Di Kota Bandar Lampung. Jurnal Sains Dan Pendidikan. Vol. 2, No.3.

Peraturan Menteri Pekerjaan Umum Dan Perumahan Rakyat Republik Indonesia Nomor 28/Prt/M/2015 Tentang Penetapan Garis Sempadan Sungai Dan Garis Sempadan Danau

Rachmah, Z., Rengkung, M. M., \& Lahamendu, V. (2018). Kesesuaian lahan permukiman di kawasan kaki Gunung Dua Sudara. SPASIAL, 5(1), 118-129.

Rachman, HPS. (2001). Kajian Pola Konsumsi dan Permintaan Pangan Masyarakat Berpendapatan Rendah Jawa Tengah dan Nusa Tenggara Barat. Dalam Jurnal Agro Ekonomi: 15 (2): 3653. Pusat Penelitian Sosial Ekonomi Bogor.

Raharjanti R.P \& T. Widiharih. (2005). Model Logit Kumulatif untuk Respon Ordinal. Jurnal Matematika Vol. 8. No.3.

Ramadhan, R. A., \& Pigawati, B. (2014). Pemanfaatan Penginderaan Jauh Untuk Identifikasi Permukiman Kumuh Daerah Penyangga Perkotaan (Studi Kasus: Kecamatan Mranggen Kabupaten Demak). Geoplanning: Journal of Geomatics and Planning, 1 (2), 102-113

Sahabuddin, H., Harisuseno, D., \& Yuliani, E. (2014). Analisa status mutu air dan daya tampung beban pencemaran Sungai Wanggu Kota Kendari. Jurnal Teknik Pengairan, 5(1), 19-28.-28.

Siregar, S. (2013). Metode Penelitian Kuantitatif. Jakarta (ID): Kencana Prenada Media Group.

Tharziansyah, M., \& Agusniansyah, N. (2016). Pola Permukiman Periferi Kota Banjarmasin Studi Kasus Koridor Jalan A. Yani Km. 6-Km. 17. INFO-TEKNIK, 5(1), 38-48.

Todaro, M. P. (2000). Economic Development (7 th edition). New York: Addison-Wasley Logman, Inc.

Wijaya, D. W. (2016). Perencanaan Penanganan Kawasan Permukiman Kumuh Studi Penentuan Kawasan Prioritas Untuk Peningkatan Kualitas Infrastruktur Pada Kawasan Pemukiman Kumuh di Kota Malang. Jurnal Ilmiah Administrasi Publik Universitas Brawijaya, 2(1), 82063. 